\title{
EXCURSION TO THE ISLE OF PURBECK.
}

\author{
Whit Mondat, May 29th, and Following Day.
}

Directors-This President and Prof. Morris, M.A., F.G.S.

(Report by The President.)*

First Day.-Owing to the distance from London, many of the members had arrived at Wareham, Swanage, and other places towards the end of the previous week, but these were largely reinforced by the party leaving Waterloo at $8.5 \mathrm{a.m}$. Wareham, 115 miles from London by road, was reached between twelve and one o'clock.

Wareham occupies a position of some importance between two rivers which unite immediately below the town, in the very centre of that inlet of the Hampshire basin known as the Trough of Poole. This Trough consists of a synclinal of Tertiary beds lying in the fold between the Purbeck axis on the south and the Dorset downs on the north. These downs occupy a block of wild and elerated chalk countr'y about 19 miles in length between the gorge of the Frome at Maiden Newton, and the gorge of the Stour at Blandford. They culminate in Rawlsbury, or Bullbarrow (Badbury Rings), said to be 927 feet above sea level-a salient of the escarpment overlooking the Vale of Blackmore. The Trough, is closed on the west, as regards the Tertiary Beds, by the curving round of the chalk in the neighbourhood of Dorchester, so that, beyond this point, the chalk area is very wide.

The Isle of Purbeck faces these northern downs. Strictly it should be described as a peninsula twelve miles in length from Worbarrow Bay on the west to Swanage Bay on the east, with a maximum width of about seven miles on the meridian of St. Alban's Head. The neck of the peninsula is crossed by a line drawn from the head of Worbarrow Bay, almost due north to the Frome at Stoke. The northern half of this peninsula is a dreary waste of Middle Tertiaries penetrated by innumerable creeks in connection with the tidal estuary of the Frome. The southern balf is composed of Secondary Rocks inclined for the most part at a high angle, and may be said to contain nearly all that is of interest in the "Islaud." It is ruled off on the north by the

* The substance of the remarks made at the previons meeting is to some extent incorporated with this report. 
highly tilted chalk ridge, and on the sonth presents its headlands, cliffs, and bays (formed entirely of jurassic rocks) to the unquiet waters of the English Channel.

The distance from Wareham station to Corfe Castle is $4 \frac{1}{2}$ miles, and, as the latter town is approached, the unique situation of the Castle is more fully realized; but before entering the gorge the party stayed to inspect the workings in the Tertiary Beds on the left-hand side of the road. For miles towards the foot of the chalk ridge the refuse heaps of these excavations for pipe-clay seam the brown heath with a line of mounds, which, at a distance, might almost be taken for moraines. These beds belong to the Lower Bagshots, and are largely associated with the leaves of dicotyledonous plants. Mr. Brodie has also noted insect remains from this horizon.

The Matcham clay works, visited on this occasion, are on the opposite side of the road to the Nordon pits (indicated in the diagram), and present some unexpected features. In the first place the beds are dipping nearly due $S$. at an angle of $15^{\circ}$, being exactly the reverse of what the average inclination of the beds must be in this region, i.e., they dip towards the longitudinal fault at the base of Knowl Hill.

\section{Section of tae Matcham Workings.}

Black Earth, and surface material, with flints-indications of sepulture, \&c.

1. Loose white sand with 1ronstone Bands at base $\quad \ldots \quad$ 20-40ft.

2. Stiff yellowish or variegated clay-"pipe-clay" ... $30 \mathrm{ft}$.

3. Pure " Potters' Clay," with leaves, \&c. … ... $8 \mathrm{ft.}$

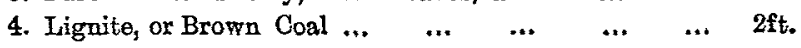
Clay

The loose sand is very full of water and exceedingly troublesome. The ironstone grits are very similar to those used for mending the roads hereabouts.

No. 2, the yellow or variegated clay, is taken off in large oblong spits, and left in the workings. No. 3 is the article so much sought after; it is a soft, white, and somewhat unctuous clay and is no doubt pretty nearly pure kaolin. In the Nordon workings the lignite (No.4) was sometimes found to be 7 or 8 feet thick, and was occasionally used as fuel by the workpeople.

From this place to Corfe Castle is only a few hundred yards. The great east and west fault once crossed, the indurated chalk is 
immediately seen dipping north about $70^{\circ}$. Belemnitella was noted in the bighest beds, which are quarried for road stone. There are but few flints in these highest beds.

The two streams which have excarated the double gap in the Chalk ridge unite just below this quarry at about 50 feet above sea level. The bigh road follows the most easterly of these gorges, having the curious insulated monticle on which the Castle stands high upon the right. At a suitable place the members dismounted from the carriages and proceeded at once to swarm up the steep acclivity beneath the eastern ramparts of the now dismantled fortress, where they were joined by the directors and the rest of the party. The day was fine and warm, and there was every opportunity of observing the physical features for which this curious spot is so remarkable. Towards the north extended the Tertiary plain just traversed, bounded in the far distance by the Dorset downs. On either flank were seen the deep gorges which separate the monticle from the rest of the Chalk ridge-Knowl Hill on the west, Challow Hill on the east. The area thus insulated may be about 20 acres in extent, measured at its base, sloping gently southwards-that is towards the town of Corfe Castle. So narrow is the outcrop of the Chalk here, owing to the high angle of dip that already at the drawbridge the Upper Greensand is reached; the monticle itself therefore must consist of the Lower and Middle Chalk. There are no signs of any transverse disturbance, or material change of strike; hence it is probable that the peculiarity of a double gap is simply due to the fact that the drainage of the longitudinal Wealden Valley behind is effected by two streams which unite just outside the chalk ridge. In all other respects the double gorge at Corfe may be regarded as analogous to those in connection with the Wealden of the south-eastern counties.

If archæologists are right, the phenomenon of the excavation was recognised by the Anglo-Saxons in the name-originally Corresgate, from the Anglo-Saxon Ceorfan, to cut; and truly it is one of nature's most impressive cuttings, though small compared with some which might be mentioned. From early times this spot, which was in a certain sense the key to the Isle of Purbeck, had been the favourite resort of the Saxon princes. In spite of what the guide books say, no one believes that the Castle, whose ruins we now see, was built by Edgar ; but there is no reason to doubt the old chronicler, who tells us that the murder of Edward 
the Martyr took place (A.D. 978) at the Hospitium of Elfrida, " ubi nune castrumi satis celebre constructum est." Thus, when self-appointed guides would show us the gateway where the unsuspecting Edward accepted the treacherous hospitality of his stepmother, we may receive the information in a non-realistic sense, and as indicating at least the spot where the gateway ought to have been at the time of the murder.

A portion of the masonry of the inner face of the S.W. wall may have been erected before the Norman Conquest according to Mr. Bond. The actual date of the present structure is not perhaps known (said to be Edwardian), but the place figures in English history during the reign of King John. It continued to be a royal fortress till the time of Elizabeth, who made it over to the Hattons, by whom it was sold in 1635 to the Bankes family, with whom it has remained ever since. Its successful defence by Lady Bankes during the Parliamentary wars, and subsequent capture and destruction, are matters of history.

After a brief interval for refreshment, the party reassembled at the Museum, where the Rev. Owen L. Mansel, of Church Knowle, gave an interesting demonstration on the fossils and on the physical history of the district. The Museum was largely stocked by the late Mr. Brodie, of Swanage. It contains capital specimens of Purbeck fossils, including some insect remains, such as the wing of a dragon-fly, a few selected slabs with Corbula, Cyrena, Unio, Melania, \&c., and many Turtle remains, including specimens of Pleurosternon ovatum, $P l$. concinnum, described and figured by Prof. Owen ; also ganoid fish and spines-Asteracanthus, Hybodus, \&c.

There are likewise some interesting fossils from the Punfield Beds and Lower Greensand, including several specimens of Vicarya, also Ammonites Deshayesii. Especially noteworthy is a species of lobster, said to come from below the "marine band" of Punfield Cove, and thus, according to Mr. Meÿer, showing the connection between these beds and the lobster beds of Atherfield.

Mr. Mansel particularly indicated specimens of marine shells obtained in a tufaceous deposit at no great distance from the town.

The route, after leaving the town of Corfe Castle, crosses the longitudinal hollow represented by the Wealden Beds, and thence ascends the steep slope of the Purbeck Beds to Kingston, which is situated on the Jurassic ridge forming the southern rampart of the Isle. 
The new church, dedicated to St. James, is a remarkable building for so remote a village. It has been constructed at a great cost by the Eldon family from stone and marble procured on the estate. The marble for the pillars has been quarried from the Paludina-beds of the Upper Purbecks at a place called Blashenwell (?). The stone for the outside has been obtained from the Burr beds of the same locality, out of quarries where there is a reversed or southerly dip. The Burr is a comminuted shell-limestone occurring at the base of the Upper Purbecks. The squared stone used in Corfe Castle is derived from the same beds. The interior mouldings of the church are made of Portland stone from a quarry about half-way between the village and Swyre Head.

This quarry, known as London Doors, was the next point inspected. It shows a very good junction between the Portland Beds and the Purbeck Beds, though somewhat different to any other junction. Being on the summit of the plateau, and situated on the line where the northerly roll is becoming very pronounced, there is nuch currature and infiltration. The irregularity of the junction, mainly produced by these two causes, could only be shown by a drawing. Moreover, the uppermost Portland Bed weathers in such a way as to produce the most misleading appearances.

As it was evident from the lateness of the hour that there would be no chance of reaching St. Alban's Head, the Director made a few observations with reference to the Portland beds of the Isle of Purbeck. There are no Cerithiun and Cyrena-beds, such as the two well-marked series observed last year in the Vale of Wardour. In the Purbeck-Portlands all the beds belong to the purely marine type, and are of great thickness. The Portland Stone is divisible into four principal groups, only two of which are well seen in this quarry.

\section{GENERALIZED VERTICAL SECTION OF THE PURBECK- PORTLANDS.}

1. The topmost bed is a pure fine-grained limestone usually quarried for lime barning. It is sometimes compact or creamy; sometimes it weathers like chalk. The natives call this bed the "Shrimp," from the quantity of the remains of a small Crustacean. Parts of this are very fossiliferous, but there is usaally no definite shell bed

$9-10 \mathrm{ft}$. 
APPROXIMATE

THICKNESS.

2. A huge Oyster Bed with many species of Monomyaria, especially Perna Bouchardi. It has an irre. gular development. Is poorly shown in this quarry, but largely developed at Tillywhim, where the Oyster Bed forms the top of the Portlands......

3. The Oolitic Series. At the Winspit quarries this $4-8 \mathrm{ft}$ contains two good tiers of freestone, each 7 feet thick. It is most likely the nppermost of these tiers which is represented at London Doors quarry. Banks of Trigonia gibbosa, \&c. $30-40 \mathrm{ft}$.

4. The Cherty Series, splendidly shown at St. Alban's Head $80 \mathrm{ft}$.

Resuming the route along the plateau towards Swyre Head, the great cirque known as the Golden Bowl suddenly discovers itself on the left. This is a good specimen of those terminal amphitheatres or horse shoes, which show to more advantage in the Jurassic rocks than in any others. Skirting the edge of this cirque at an elevation of over 600 feet, with Encombe House and grounds deep in the hollow below, the party at length arrived on the level summit of Swyre Head, which is the highest point of the Portlandian escarpment- 677 feet-and the citadel of the Isle of Purbeck.

Swyre Head.-The afternoon was fine and fairly calm, but the light was unfarourable for obtaining a good panoramic view, especially towards the west. The outlines were traceable, but they were somewhat indistinct. White Nore bears W. by N, 10 miles, Portland W.S.W. 16 miles, the Needles E.N.E. 22 miles. All these were visible. Aided by the map and diagrammatic section, some topographical indications, just flavoured with geology, sufficed to bring home to the members of the party the general features of the scene. The Head itself forms the southern termination of a promontory which projects from the Portlandian plateau, having on the east the deep bowl of Encombe, and on the west the wider and nobler sweep of rock and grassy slope, at the bottom of which the little bay of Kimeridge reposes. This beautiful amphitheatre, facing the south, and cut off, as it were, from all the rest of the world, is remarkable for its fertility, due no doubt to the rich soil produced by the highly phosphatic Kimeridge Clay of this district mixing with the sand and lime of the overlying formations. An anticlinal, transverse to the main 
axis of flexure, traverses this hollow, and brings up more than 100 feet of the Lower Kimeridge in the Bay itself. It is not unlikely that something of the nature of a quaquaversal exists thereabouts, since from the hollow of Kimeridge Bay the beds dip west towards White Nore, north towards the Trongh of Poole, and east, through Swyre Head, West Hill (terminating in Encombe Point), and Emmit Hill (terminating in St. Alban's Head), all the way to Durlston Head, six and a half miles E. by S. of Swyre Head, where the beds, which are here nearly seven hundred feet above the level of the sea, plunge beneath it. The southeastern corner of the Isle of Purbeck, including St. Alban's Head, is scarcely affected, therefore, by the chief or east and west axis of disturbance, its dips being in the main easterly. Thus a line drawn from St. Alban's Head to the centre of Weymouth Bay would pretty nearly follow the axis of the WeymouthPurbeck anticlinal, where the beds in the immediate vicinity of the axial line are but little affected by it. As this line is for the most part abont two miles out to sea, the southern wing of the anticlinal is lost until we reach Weymouth Bay itself.

The curiously indented and highly tilted coast facing this axis is so much foreshortened, as seen from Swyre Head, that the effects of the very remarkable scenery of Worbarrow Bay, Mewps Bay, Lulworth Cove, \&c.-all outside the Isle of Purbeck-are not fully realized from this point. Perhaps the most striking feature in the landscape is the abrupt ridge of Chalk which is stretched like a cord across the centre of the island, and which may be traced from White Nore through Bindon Hill to Flowersbarrow, where the Isle of Purbeck commences. Next succeeds that portion of the ridge knowu as Purbeck Hill, lying N.W. of Swyre Head. Almost due north is Creech Barrow, quite 600 feet high, just outside the line of the chalk ridge. This rather singular hill is formed of Tertiary Beds, chiefly the Lower Tertiaries with a small capping of Bagshots, held up in a fork of the great longitudinal fault running on the north side of the chalk ridge. From this point the chalk ridge becomes lower in Knowl Hill, and continues to fall all the way towards the double gap at Corfe, from whence it rises slowly through Challow Hill to Ninebarrow Down, where Cordington attains 654 feet-the highest point of the whole ridge.

One of the most interesting features to note is the steady lowering of the chalk ridge towards the double gap at Corfe, and 
then the sudden declivity of the double gap with the castlecrowned monticle in the centre. At the same time one cannothelp noticing that the ridge has been pierced where it seems to form the head of a slight curve. This gradual falling away of the chalk ridge towards the breach seems to point to long-continued erosion of some sort previous to the final excavation of the double gorge by the two streams which drain the central hollow. Doubtless the drainage area and consequent accumulation of water was greater formerly. The real dividing ridge of the island-the water parting-is the Jurassic plateau. All the waters falling on the north side of this parting, except such as flow into Swanage and Worbarrow Bays, must pass out at Corfe. Now the area draining into Worbarrow Bay is exceedingly small, and the basin of the Puddle Brook large in proportion; and it thus happens that this stream has done its work of excavating the western gap at Corfe much more effectually than the Byle Brook has in excavating the eastern gap. A reference to the map will show at once that the catchment basin of the Byle Brook is seriously interfered with by a low transverse (N. and S.) watershed, which directs much of the rainfall into the stream entering the sea at Swanage. When the land was more extensive, a different state of affairs must have prevailed, and, as regards the deep hollows on the south side of the water parting, these seem to have formed the heads of valleys passing through a district which has been largely eaten up by the sea, and is even now undergoing a rapid loss.

It became necessary to give up the notion of visiting the workings for "coal" on the cliff near Little Kimeridge, but the view towards St. Alban's Head and Emmits Hill was so inviting that a large portion of the members agreed to accompany the President in order to obtain a nearer peep at the Kimeridge Clay and Portland Sand of those localities. The Upper Kimeridge of these parts is reckoned to be nearly 700 feet thick, and is characterized by paper shales, bituminous shales, and cement stone beds of various qualities. These cement stone beds in their continuation out to sea form the Kimeridge ledges. The coal beds now worked are in the lower part of the Upper Kimeridge, and consist of a block bituminous coal, two feet thick, and above this, of a mass of bituminous shales, ten or twelve feet thick, but variable as to quality. Some of this coal contains a large amount of gas. 
One analysis gives 61 per cent. of volatile matter with a balance of 13 per cent. carbon and 26 per cent. ash. The gas has a high illuminating power, but smells horribly. It is generally supposed that the hydrocarbons have been distilled from the putrefaction of animal matter. The material occasionally has a market for the production of asphalt and other compounds. These Upper Kimeridge Beds have a somewhat local development, and have, on the whole, a different fauna from the Lower Kimeridge as exposed in Ringstead Bay. Palæontologically they are characterized by the absence of Exogyra virgula, Ostrea deltoidea, and Rhynch. inconstans, and by the prevalence of Lucina minuscula, Discina latissima, and Lucina lineata. Am. biplex is very abundant.

A somewhat scrambling walk bronght the party, after rounding the picturesque headland which terminates in Encombe Point, to the Kimeridge Clay of Chapman's Pool, a very noted locality for Upper Kimeridge fossils.* There was but little time for close search, and the beds were very foul, but a few of the more characteristic forms were noted, and one or two tolerable specimens secured. Above the blue shaly clays of this place the bare slopes of Portland Sand are seen to be surmounted by the cherty calcgrits which form the base of the Purtland Stone capping the precipices of Emmit Hill, \&c. This Portland Sand is a strange mixture of clay, sandy clay, and hard bands, so that few authors agree as to the thickness to be assigned to it. Fitton says 120 feet, $\mathrm{Mr}$. Blake 240 feet. The meaning of this is that there is no good line of demarcation between this formation and the Kimeridge Clay. The thickness of the Upper Jurassics in the Isle of Purbeck is very great, being however pretty much the same as was found to obtain in the Subwealden boring, which must be regarded as being situated in that same fold of the old sea bed which received such immense accumulations during the close of the Jurassic period.

The party now made the best of their way through the picturesque hollow of Renscombe to the farm house at Weston, where carriages were ready to convey them to Worth. Here the last stragglers joined, and a rapid drive through Langton, and past innumerable workings for the Purbeck Stone, which is sought beneath the surface, brought the party to Swanage.

* Cf. Blake, "Q. J. G. S.," Vol. xxxi., p. 198 ; and Brodie, " Proo. Geol. Aseoc.," Vol, iv., p. 517. 
Second Day.-It became evident that in order to do justice to the Purbecks of Durlston Bay, the visit to Tillywhim must be abandoned. The members assembled accordingly at the foot of the zigzag path in the very centre of Durlston Bay, at the spot where the fault marked $f^{f}$ in the section Fig. 2 strikes the coast. This is a good point for commencing. The effect of the throw is very conspicuous. As one faces the cliff, the hard Cinder Bed on the left, which is about the centre of the Middle Purbecks, is brought into juxtaposition with the soft lower beds of the Lower Purbecks on the right. The effect is not exactly the same as is shown in the section, since all the beds at the fault are lower on the coast than in the actual line of section. The amount of throw may be about 150 feet. The thickness of the Purbecks in Durlston Bay is variously estimated. Mr. Bristow's vertical section gives 370 feet.

The advantage of commencing at this spot consists in being able to work up the entire sequence in ascending order from here to Peverel Point, the very lowest beds alone being concealed. Professor Morris gave a sketch of the fauna and subdivisions of the Purbecks, together with a notice of the physical conditions which, in all probability, accompanied the deposit, and a comparison of these beds with the Purbecks of other areas. He especially dwelt upon the change from fresh water to marine conditions, showing that, although the change from marine through brackish to fresh water is gradual, the change from fresh water to marine conditions was abrupt, indicating, as it were, sudden inroads of the sea. He also ventured to call in question the absolute change of species said to occur in the three subdivisions of the Purbecks. The remarkable vertebrate fauna was then alluded to, and special description given of the mammalian remains discovered by Messrs. Beckles and Brodie, and described by Prof. Owen and Dr. Falconer. Up to the year $1856 \mathrm{Mr}$. Beckles had collected 28 individual and Mr. Brodie seven individual specimens-35 in all, and these consisted of fourteen species, mostly insectivorous marsupials, though one (Plagiaulax) was believed to be an herbirorous quadruped allied to the kangaroo-rat (Hypsiprymnus).

The members then distributed themselves along the beach, but always making some progress towards Peverel Point. Species of Cypris, some tuberculated, others not, were discovered, together 
with specimens of Serpula coacervata, Melania, Paludina, Planorbis, Cyclas, Cyrena, \&c., and in the more marine bands, Pecten, Modiola, Corbula, Ostrea, \&c. The Lower Purbecks are remarkable for immense concretionary masses of gypsum; they contain no workable stone. At the base of the Middle Purbecks occurs a sort of marly dirt bed a few inches thick, in which the mammal bed is found. There was some difference of opinion as to which was the real bed, but this was finally settled to the satisfaction of all parties. The Middle Purbecks are, on the whole, the most interesting and valuable. They contain five workable beds of stone. Three of these are above the Cinder Bed. Two are below. The following is the order of their occurrence :-1. The Laning Vein. 2. The Freestone Vein. 3. The Downs Vein-the Cinder, a thick bed of Ostrea distorta and other shells. 4. The Cap and Feather. 5. The New Vein. Remains of turtle and fish are frequently found in these beds by the workmen. The base of the Upper Purbecks is characterized by the Burr Beds-not now worked-near Swanage. Above these are the Unio beds, and in this series occurs the Crocodile bed-a blue-hearted, gritty limestone full of skin and teeth and other remains of Goniopholis crassidens, together with wood, fish palates, turtle. \&c. Abundance of fragments were secured. With the Paludina-beds (Purbeck marble) of Peverel Point this most interesting ascending section terminates. There is a good deal of complex folding here, and the principal rock beds are thrown into a synclinal, which may have the effect of strengthening the Point, and thus saving the town of Swanage.

In the afternoon the party walked along the shore of Swanage Bay, hurrying past the Hastings.Wealden beds, which, though said to be 1,800 feet thick, are but poorly fossiliferous. Variegated clays and sands, dipping northwards at an angle which increases as the chalk is approached, are the chief features. Bones of Iguanodon have rolled out of them occasionally.

There was a two-fold reason for this haste. Firstly, a large portion of the party wished to catch the up train from Wareham. Secondly, it was felt that the centre of interest lay in Punfield Cove, not only because of the discussion between Messrs. Judd and Meÿer as to the so-called Punfield Beds, but because the monotonous character of the strata undergoes a considerable 
change at this place, and the beds immediately underlying and at the base of the chalk possess features of considerable interest. The beds involved in the Punfield controversy, including what Professor Judd allows to be "Upper Neocomian," are over 200 feet thick (these are all included in the upper part of $h 1$ of Mr. Bristow's section). The Gault cannot be measured ; the Upper Greensand, according to Fordham, is 70 feet thick, the Chloritic Marl $4 \mathrm{ft}$., the Chalk Marl 40ft., the grey Chalk $100 \mathrm{ft}$. The dip is for the most part about $65^{\circ}$ towards the $\mathrm{N}$.

The party being assembled in full view of the Punfield section, at the most convenient spot for noting the somewhat obscure features of the cliff, the Directors first gave a brief history of the controversy on the Punfield Beds, and, secondly, endeavoured to point ont the various horizons which are mentioned in the writings of Messrs. Judd and Meÿer, so that afterwards each horizon might be separately examined and identified. The latter task proved the more difficult of the two.

As regards the points in dispute, Mr. Meÿer observes that he and Prof. Judd agree in the main as to the stratigraphy, though in a second paper he supplements his section with some important details. The sequence below the Gault is somewhat as follows in descending order :-

1. Grey Clays alternating with ferruginous sandy beds. Exogyra sinuata, Panopea neocomiensis. "Upper $\begin{array}{ccccc}\text { Neocomian" } & \ldots & \ldots & \ldots & \ldots \\ \text { The Cypridiferous Beds with their bands of Limestone }\end{array}$

ft. in. made up of CxreNa, Ostres, \&c. Not seen either by Judd or Mëyer

... $\quad \ldots \quad \ldots$

3. Ferruginons sands with interlaminated clays and lignite, in the middle several bands with oyster and $\begin{array}{llllll}\text { other marine shells } & \ldots & \ldots & \ldots & \ldots\end{array}$

4. "The marine band of Punfield," with a rich and novel fauna, representing, according to Mëyer, in common with the rest of the Punfield Beds, three elements, viz:-(1) A set of marine or brackish water mollusca peculiar to this locality and to the coal-bearing strata of Eastern Spain. (2) About four species of brackish water molluscs, a Cardium, a small Ostrea and Corbula or Potomomya, and a species of Mytilus. (3) A group of fossils com. mon in the Neocomian Beds of Atherfield and Shanklin $\begin{array}{llllll}\cdots & \cdots & \ldots & \ldots & \ldots\end{array}$ 
With the marine band, according to Prof. Judd, the Punfield series terminates, being succeeded in descending order by the Variegated Beds of the Wealden. But Mr. Meÿer has obtained abundant indications of marine shells a long way below this, and he places 100 feet of beds between the Marine Band and the Variegated Beds of the Middle Wealden. Continuing the section downwards. we have, according to Më̈er-

5. Blue Clay with Arca and Marine Crastacean (Atherfield " lobster")

6. Band containing abundance of Lower Greensand fossils.

7. Blue Clay which may be on the horizon of the Perna-bed at Atherfield.

8. GrTT-BAND associated with Cypis and remains of small fish.

9. Blue oypridiferous shales and clays of the UPPER WEALdEN, for the most part masked.

The difference of opinion between Prof. Judd and Mr. Meÿer amounts to this-the former regards the beds between the admitted Upper Neocomian and the Variegated Wealden as a "fluvio-marine" series, having certain analogies with the coalbearing beds of Utrillas, in Eastern Spain. Mr. Meÿer, on the other hand, regards the whole as a littoral facies of the Lower Greensand, and he prefers to place them on the horizon of that of the Isle of Wight rather than correlate them with any portion of the underlying series as developed in that island.

The second duty of the Directors was to identify the several horizons detailed in the preceding section. This was not quite so easy a task. Mr. Meÿer's grit-band was seized upon as a datum line, and from this line upwards the investigations were carried. That portion of the party bound for Wareham had to be satisfied with a rapid scamper across the strike, and hasty identification of the beds as far as the Upper Greensand. This was effected under circumstances of some difficulty, but on the whole the general sequence and character of the beds was fairly made out. Those who had more time at their disposal then returned to the datum line, viz., the Grit-band which stands out well in the slippery cliff. In order to do the thing thoroughly, coats were taken off, and relays of members took their turn at the diggings until a considerable trench was formed. It was then found that the accumulation of material sliding forwards preclnded all further investigation without heavier tools and more systematic action, such as there was no time to apply. The Grit-band dips northwards at 
about $65^{\circ}$, and the overlying beds are strictly conformable. Subjoined is an account of the section cleared, which may be deemed fairly accurate as far as it goes. From above downwards :-

\section{Base or tre Punfield Section.}

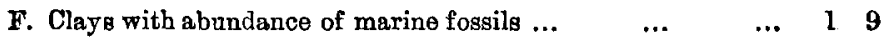

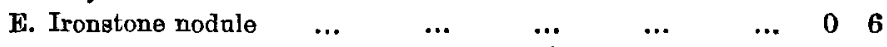

D. Opper black Cypris-Clay, with more of the taberculated

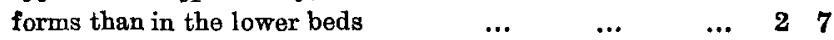

C. Banded and rariegated greyish sandy clays. Unfossilife$\begin{array}{llllllllll}\text { rons } & \ldots & \ldots & \ldots & \ldots & \ldots & \ldots & 4 & 3\end{array}$

B. Cypridiferons black clays with two species of Cypris $\quad \ldots \quad 0 \quad 9$

A. GRIT-BAND ; a lime-bound quartz grit with fragments of bone. Shales and clays of the UpPer WeALdex.

Total measured $\ldots . \quad \ldots \overline{9 \quad 10}$

It is evident, therefore, that a Wealden fauna extends above the Grit-bed to a higher point than supposed by Meyer. The nodule line, $\mathrm{E}$, represents the junction bed between the $W$ ealden and Lower Greensand fanna. How far the top of this fauna lies below the original "marine band" the members had no means of judging. *

These operations took up so much time that the contemplated walk across Ballard Down to Studland Bay had to be deferred to another opportunity, and thus the original programme for the second day was incompletely carried out, both as to its commencement and termination.

* It has quite recently come to my notice that there is, in the British. Musenm, a very fine specimen of a Vicarya, forming part of a collection from the Isle of Wight. The shell is in good condition, and probably came from Atherfield. It is placed amongst the Lower Greensand fossils of that locality.-W.H.H. 